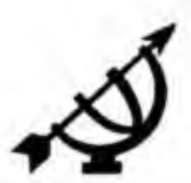

\title{
Reformasie as herstel van die ware diens van God: enkele aanwysers by Calvyn en
} Zwingli

\author{
L.F. Schulze \\ Skool vir Kerkwetenskappe \\ Potchefstroomse Universiteit vir $\mathrm{CHO}$ \\ POTCHEFSTROOM
}

\begin{abstract}
Reformation as restoration of the true service of God - some indicators in the work of Calvin and Zwingli

In this article an attempt is made to interpret the 16th century Reformation from a rarely mentioned, yet very real perspective, viz., as a restoration of the true service of God. It is indicated that the true service of God is an overarching concept, encompassing more than simply an ecclesiastical reform, or a return to the Bible. Besides these aspects, true service of God implies the renewal of life with all its social, economical and political overtones, which cannot be discussed in full in an article. Data drawn from some works of Calvin and Zwingli will hopefully prove the validity of this perspective and offer Christians in the "new South Africa" thought-provoking ideas which should be put into action.
\end{abstract}

\section{Inleiding}

Wat was die Reformasie van die 16de eeu? Op hierdie vraag is daar deur die loop van die afgelope vier eeue verskillende antwoorde gegee. Ons noem 'n aantal: dit was eintlik maar 'n reaksie teen misstande in die Rooms-Katolieke Kerk; dit was 'n herstel van die kerk, waardeur kerklike sake (leer, diens en tug) weer in orde gebring is; dit was 'n reveil, 'n geestelike herlewing wat duisende tot bekering gebring het; dit was 'n sektariese rewolusie wat die kerk verskeur het; dit was 'n vroeg-burgerlike rewolusie. Lesers sal in die voorlaaste opvatting die siening van 
Rome $^{1}$ en in laasgenoemde opvatting die siening van kommunistiese historiograwe herken.

Wat was die Reformasie? Hierdie skynbaar bloot akademiese vraag is vr ons as kinders van die Reformasie tog van eksistensiële belang. By die beantwoording van hierdie vraag word al bogenoemde opvattings nie krities bespreek nie. In plaas daarvan word 'n ander perspektief op die Reformasie gestel, naamlik dat dit 'n herstel van die ware diens van God was.

Die ware diens van God is 'n omvattende begrip. Daaronder sal die reformasie van die kerk kortliks aandag kry. 'n Besonderheid in die reformasie van die kerk, naamlik 'n verkeerde soort "nagmaalsviering", sal in die lig van 'n preek van Calvyn meer aandag ontvang, nie net om Calvyn se afkeer van bygeloof aan te toon nie, maar veral om sy sorg vir 'n "uitwendige vorm" van die kerk in die lig te stel. Ten slotte sal die wyer omvang van ware diens van God as vernuwing van die lewe met enkele flitse belig word.

\section{Begrensing van die onderwerp}

Die subtitel is doelbewus by die titel van hierdie artikel aangebring. Dit spreek immers vanself dat die omvattende opskrif onmoontlik binne die bestek van 'n artikel ter sprake kan kom. Die ware dıens van God omvat immers die lewe in al sy fasette. Indien so iets onderneem sou word, sou 'n mens byvoorbeeld by Luther moes begin en veral sy (en Melanchthon se) hervorming van die onderwys in die visier moes kry. Dit sou die aandag ook heenlei na die Akademie van Genève en die hele kwessie van humanisme en Reformasie aan die orde stel (De Jong, 1967; Van der Walt, 1984; Schulze, 1992). Omdat die Reformasie in Genève nie deur predikante nie maar (soos op baie ander plekke) deur die Raad, dit wil sê, die regering geünisieer is, sou die implikasies van die (destydse) simbiose van kerk en owerhede bespreek moes word (kyk byvoorbeeld Wallace, 1988:27-128), waarby ook Bucer se De regno Christi betrek moes word (kyk hieroor bv. die fyn analise van Bucer se advies aan die Engelse koning oor die Sondagviering deur De Kroon, 1997)

Bostaande enkele (hipotetiese) voorbeelde is voldoende om die wydheid van die onderwerp en die noodsaak van die beperking aan te dui.

1 Rome se skerp afwysing van die Reformasie het in ons ekumeniese klimaat, en veral sedert die Tweede Vatikaanse Konsilie, meer simpatiek geword. Kyk byvoorbeeld Küng, 1969; Ganoczy, 1987; Schützeichel, 1997; Manns, 1983, wat sy werk oor Luther soos volg afsluit: "Wie dumm war doch die Redensart, mit der wir Jahrhunderte hindurch den Nagel auf den Kopf zu treffen glaubte, indem wir einander nachsagten: 'Evangelish ist gut leben, katholish gut sterben' Wer sich an Luther halt, der lebt gut und stirbt noch besser, weil am Ende des dunklen Tunnels jemand steht, der uns lieb hat und auf den wir uns freuen durfen." 


\section{Reformasie van die kerk}

In Februarie 1544 het Karel V (1500-1558), die keiser van die Heilige Romeinse Ryk, die vierde ryksdag van Spiers byeengeroep. Bucer, die hervormer in Straatsburg, het Calvyn versoek om die geleentheid aan te gryp om aan die keiser 'n dringende versoekskrif voor te lê. Daarin word gepleit dat Karel V'n algemene kerklike konsilie, soos gebruiklik was in die vroeë kerk, saamroep. Calvyn het aan die versoek van Bucer voldoen. Die resultaat was sy bekende traktaat, Die noodsaak van die reformasie van die kerk. Hierin het Calvyn die mankemente van die (Roomse) kerk duidelik uitgestippel. Tegelykertyd was dit 'n kragtige regverdiging van die Reformasie. Die geskrif het 'n diep indruk op die ryksdag gemaak en die keiser se felheid teen die hervormingsbeweging laat afneem $(C$. $\operatorname{Tr} .1: 121)^{2}$

Uit watter dinge bestaan die Christelike godsdiens, het dit 'n staanplek onder ons en word sy waarheid bewaar? Hierop antwoord Calvyn in sy voorlegging dat daar twee hoofsake is, wat alle ander aspekte insluit en waarsonder die Christelike godsdiens 'n leë dop sou wees, naamlik 'n kennis, “... first, of the mode in which God is duly worshipped; and, secondly, of the source from which salvation is to be obtained" ( $C$. $\operatorname{Tr} .1: 126)$. Daarna kom die sakramente en die kerkregering, wat ingestel is om genoemde twee hoofsomme van die leer te bewaar en vir geen ander doel aangewend mag word nie. Calvyn verduidelik dit nader deur te sê "... that the rule in the Church, the pastoral office, and all other matters of order, resemble the body, whereas the doctrine which regulates the due worship of God, and points out the ground on which the consciences of men must rest their hope of salvation, is the soul which animates the body ..." (C. Tr. 1:126-127)

Nou, sê Calvyn, moet ons sien wat die regte verering (worship) van God behels. Die diepste fondament van ware verering is om God te erken, soos Hy inderdaad is, as die bron van alle voortreflikheid, geregtigheid, heiligheid, wysheid, waarheid, mag, goedheid, genade, lewe en verlossing; om in ooreenstemming hiermee aan Hom die eer toe te bring vir alles wat goed is, Hom alleen in alle dinge te soek en in alle nood na Hom alleen toevlug te neem. Hieruit ontstaan gebed, hieruit lof- en danksegging - bewyse van die eer wat ons aan Hom toeken. Dit is die ware heiliging van sy Naam, wat Hy bo alles van ons vra (kyk C. Tr. 1:127)

2 C. Tr. = Calvin's tracts and treatises (kyk bibliografie vir volle besonderhede). Die uitgawe bevat nie net werke van Calvyn nie maar byvoorbeeld ook Beza se lewensbeskrywing van Calvyn, Kardinaal Sadoletus se brief aan die Raad van Genève, Pous Paulus III se brief aan keiser Karel $\mathrm{V}$ en in inleiding en historiese aantekeninge van T.F. Torrance. Die betrokke werk van Calvyn is in dl $1: 123-234$. 
In so 'n teosentriese ere-diens neem die Nagmaal 'n sentrale plek as verbondsteken en -seël in. Oor die regte en sobere Nagmaalsviering het Calvyn hom meermale uitgelaat. ${ }^{3}$

\section{Nagmaalsviering is geen Misoffer nie}

Van belang is die feit dat Calvyn ook in sommige van sy preke gedurende 1549 weer op hierdie onderwerp teruggekom het. Dit was nie te wyte daaraan dat Calvyn "niks anders gedoen het as om teen die Roomse Kerk te skreeu nie". Só het sommige van sy teenstanders hom verwyt (Peter, 1984:25). In werklikheid was die preke daarop gemik om aan Protestante in Roomse lande (veral Frankryk) leiding te gee. Hulle posisie was immers benard. Oral het die agente van die Inkwisisie en van die Roomse state probeer om "ketters" uit te snuffel, te vang, soms te martel, en selfs om die lewe te bring. Gesien teen hierdie agtergrond, is dit begryplik dat die vrae deur die jare maar altyd weer gevra is óók aan Calvyn: Wat moet ons as Protestante in Roomse lande doen? Hoe moet ons ons gedra? Dit was geen teoretiese vrae, wat maar agter 'n lessenaar sonder veel skade na die een of ander kant toe beantwoord kon word nie. Dit was brute vrae, 'n geroep uit die dieptes, eksistensieel gelaai - vrae wat in die mees naakte sin met lewe of dood verweef was. Daarop móés Calvyn, die pastor (ná sy twee oop briewe en sy twee latere traktate), maar weer advies uit die Woord gee. Hierdie keer doen hy dit in enkele preke wat gedurende 1549 op Sondae gelewer is (hy moes al om die ander week ook daagliks preek).

Die Sondagpreke het vir 'n groot deel van 1549 bestaan uit preke oor die Psalms (soggens) en oor Hebreërs (namiddags - kyk die chronologiese tabel in Parker, 1992:150). Om 'n "belofte wat hy gemaak het" te vereffen (Peter, 1984:24) het Calvyn vier preke uit 1549 versamel, geredigeer en uitgegee met die titel: Vier preke oor baie nuttige sake vir ons tyd, tesame met 'n kort verklaring van Psalm 874

3 Die eerste maal so vroeg as 1537 ('n jaar na die verskyning van die eerste uitgawe van sy Instntusie), toe hy twee traktate in die vorm van oop (d i ongetekende) briewe geskryf het Die eerste traktaat was On shunning the unlawful rites of the ungodly and preserving the purity of the Christian religion met 'n subtitel: "A letter by John Calvin to his dear and very excellent friend, N.S". Die tweede was Popish priesthood. In sy lewensbeskrywing van Calvyn vertel Beza dat die eerste bnef aan Nicholas Chemin en die tweede aan Gerard Roussel gerig is ( $C$. Tr I:ixix). Ses jaar later volg die Petit Traicté (1543 - na my wete nog nie vertaal nie, volle titel en teks in $\mathrm{CO}$ 6:537-588) Op reaksie teen laasgenoemde volg 'n apologie, Excuse de Jehan Calvin à Messieurs les Nicodemites (1544) - resente Engelse vertaling deur Eric Kayayan (1997a).

4 Quare sermons tralctans des matieres fort utiles pour nostre temps, avec briefve exposition du Pseaume 87, Robert Estienne, 1552 (CO 8:369-452; Ndl. vert. deur Douma en Van der Vegt, 1941, 5:7-103; vgl Calvyn, 1941). Dit was 'n wonderlike beskikkıng dat daar vroeg in 1549 'n 
Hier volg enkele opmerkings - net oor die eerste preek. Gemeet aan moderne homiletiese standaarde sou die preek as "ongebalanseerd" beskou kon word: te min eksegese en te veel toepassing. In die Nederlandse vertaling omvat die verklaring van die teks (Ps. 16:4-6) kwalik meer as 'n bladsy, terwyl die "toepassing" bykans sewentien bladsye beslaan. Hier troos Calvyn nie (behalwe in 'n paragraaf aan die einde). Inteendeel, dis 'n besonder skerp en hartstogtelike preek, 'n briljante redevoering waarin die pastor weifelende Protestante wil wegruk uit die komende oordeel van God.

Daar was naamlik in Roomse lande Protestante wat ter wille van hulle lewe en welsyn maar uiterlik aan die Roomse seremonies deelgeneem het. Hulle het ook, soos ons mense maar is, hulle gedrag probeer vergoeilik en hulleself met Bybelse argumente probeer regverdig. Dit is hulle argumente waarteen Calvyn skerp reageer.

In sy preek sê Calvyn: Daar is sommige mense wat God (as Protestante) in waarheid wil dien maar tegelyk aan die Roomse seremonies ter wille van hulle lewe bly deelneem. Hulle verdedig hulle praktyk met die argument dat uitwendige deelname aan die afgodiese en bygelowige Roomse seremonies bloot 'n geringe sonde is. God wil, so sê hulle, in die gees (en waarheid) gedien word en daarom is deelname aan die afgodiese seremonies sonder betekenis. 'n Mens kan immers nie afgode dien as jy nie jou vertroue in hulle stel nie.

Ja, sê Calvyn, God wil in die gees gedien word. Dit hou egter nie in dat die uitwendige gedrag sonder betekenis is nie. In die Bybel word immers dikwels van die buig van die knieë en die ophef van hande gepraat. Wat van Daniel en sy vriende, wat geweier het om Nebukadnesar se beeld te aanbid? Indien hierdie goeie sofiste dáár was, sou hulle die drie diensknegte van God bespot het: Arme drommels, dit is geen verering as julle nie geloof daaraan heg nie!

Só probeer Calvyn hierdie mense oortuig dat deelname aan Roomse seremonies geen kleinigheid is nie maar ' $n$ weerspreking van hulle geloofsbelydenis - daardie plegtige belofte wat ons gemaak het. As iemand hierdie belofte verbreek, skend hy die eer van God en betoon hom 'n lafaard wat openlik uit die Christendom dros.

Franse vlugteling, Denis Raguenier, in Genève kom skuiling soek het. Hy het gou sy staal as (snelskrif)skrywer getoon en was sedert September 1549 tot met sy dood (einde 1560 of begin 1561) pal op sy pos om Calvyn se preke te noteer en daama voluit uit te skryf. Raguenier se werk is daama deur een van sy helpers voortgesit tot by Calvyn se oorlye in 1564 . Hierdie vier preke was van die eerstes wat Raguenier afgeneem het en wat Calvyn dus kon redigeer en persklaar maak. Danksy Raguenier se geweldige werk beskik ons vandag oor ongeveer 2500 preke van Calvyn (Peter, 1984.23), waarvan die oorgrote meerderheid eers tans besig is om in een boekdecl na die ander van Supplementa Calviniana te verskyn. 
Daar is ander wat oortuig is dat deelname aan Roomse seremonies hoegenaamd geen sonde is nie, omdat God niks méér van ons vra as om Hom met ons hart te dien nie.

Inderdaad, sê Calvyn, wanneer hy hierdie mense se argumente in sy preek teëspreek, maar dan moet ons nie dubbelhartig wees nie. Ware integriteit hou in dat die liggaam nie anders as die hart sal handel nie. Ons moet God met ons hele hart dien, ja, maar aan wie behoort die liggaam? Paulus spoor ons aan om die Here in albei te verheerlik omdat hart en liggaam albei aan Hom behoort (1 Kor. 6:20). Hoe kan ons die opstanding van die liggaam verwag as Christus nie Verlosser van liggaam en siel is nie? Die Skrif noem tog ons liggaam 'n tempel van die Gees en sê dat ons lede van die liggaam van Christus is (Ef. 5:30), wat inhou dat ons, liggaam en siel, met Hom verenig is. Daarom kan niemand sy liggaam met een of ander bygeloof bevuil sonder om hom te onttrek aan hierdie heilige unie waardeur ons lede van die Seun van God geword het nie. Ek sou graag van hierdie spitsvondige leraars wil weet, gaan Calvyn verder, of hulle die doop net in die siel ontvang het. Het God dit (die doop) nie verorden om 'n teken te wees wat in ons vlees ingegrif is nie? Word die Nagmaal net deur die siel ontvang, en nie ook met hart en mond nie? 5

Daar is 'n derde groep Protestante wie se argumente in sy preke betrek word. Hierdie Protestante erken dat afgodery afskuwelik is maar ontken dat dit op die Roomse diens van toepassing is. In Calvyn se antwoord hierop staan offer sentraal - soos in Psalm 16:4(b), wat in die Franse teks lui: "Ek sal nie gemeenskap hê met hulle offers van bloed nie".

Elke vorm van afgodery, betoog Calvyn, is 'n ontaarding van die ware diens soos in die Wet voorgeskryf. Die geval van die twee goue kalwers van Jerobeam illustreer dit. Nou is dit duidelik dat die Pouslike Mis en die Here se Nagmaal so onversoenlık met mekaar is soos die offers van Moses met dié van Jerobeam. Hoe durf daardie mense dan na die Mis gaan onder voorwendsel dat dit maar 'n varasie (Fr. disguisement) op die Nagmaal is? Die Mis is immers 'n ontkenning van die dood van Christus. "Ek sal nog meer op die man af praat: die Mis is 'n offer waardeur die Pousgesindes Jesus Christus wil offer om hulle met God te versoen."6

5 Kyk Calvyn se uiteensetting in $\mathrm{CO} 8,381-382$.

6 Ie parleray encores plus priveement: La Messe est un sacrifice auquel les Papistes veulent offrrr lesus Christ pour se reconcilier à Dieu (CO 8, 385). Let egter op die omrulling van onderwerp en voorwerp in Paulus se utspraak (2 Kor 5:18): “... God, wat ons met Homself versoen het deur Jesus Chnstus ..." 
Daar is sommige, sê Calvyn, wat wel van die Mis af wegbly maar die parogieMis bywoon, omdat hulle meen dat dit meer met die Nagmaal ooreenkom. Dis egter onwaar, want die parogie-Mis is soos 'n slegte vrou wat haar met haar man se naam dek ten einde eerbaar voor te kom. Dis die mees algemene afgodery wat vir almal toeganklik is. In der waarheid is die parogie-Mis ingestel om Christus te offer en sodoende versoening met God ten behoewe van lewendes en dooies te bewerk. Bowendien word dáár 'n stukkie brood aanbid asof dit die Seun van God is! (vgl. CO 8, 385-386).

Hierdie preek benadruk nie hoe die Nagmaal gevier moet word nie, maar toon duidelik hoe dit nie gevier moet word, en wat dit nie is nie. Aan die weifelende Protestante in Roomse lande benadruk Calvyn met alle mag dat die Nagmaal nie 'n "Protestantse Mis" is nie, dat die twee hoegenaamd niks gemeenskapliks het nie. In hierdie skerp preek hoor 'n mens die oproep aan daardie Protestante om ten alle koste (ook, as dit moet, ten koste van hulle lewe) aan hulle geloofsbelydenis getrou te bly en ook in hulle viering van die sakrament aan die ware diens van God vas te hou. ${ }^{7}$

\section{Terugblik}

Calvyn se skerp afwysing van die Mis moet teen die agtergrond van die laatMiddeleeuse Roomse kerkdiens gesien word, naamlik, in die woorde van Locher (1981:8): "Our salvation is achieved through the performance of the liturgy". Calvyn het hierdie opvatting as 'n soort bygeloof gesien wat die eenmalige kruisoffer van Christus en die genadige belofte van die soewereine God in gedrang bring. 8

Daar lê egter ook nog 'n ander betekenis in die preek wat hier benadruk moet word. Ons kan dit heel eenvoudig die betekenis van die liggaam noem, maar dan

7 In sy preek oor 2 Timoteus 3:16-17 (CO 54, 290) verduidelik Calvyn waarom die prediker soms skerp taal moet gebruik; dat weerlegging (1953-vertaling) soms nie genoeg is nie maar ook teregwysing (Fr. correction) nodig is: "... that is, that we may be, so to say, chastised by God's Word, to reform us, so that we may be drawn out of our vices" (Parker se vertaling, 1992:14).

$8 \quad$ In sy Byvoeging by die noodsaak van die reformasie van die kerk wys Calvyn die nooddoop kategories af as 'n poging om die onwrikbare verbondsbelofte van God met menslike handelinge te probeer stuit en gevolglik in wese kragteloos te maak Volgens Rome kon die doop van klein kindertjies wat nic aan die lewe sal bly nie, selfs deur 'n leek bedien word omdat die kind daarsonder nie die saligheid kan verkry nie Calvyn se afwysing van die nooddoop werp ook lig op sy afwysing van die Mis in die preek oor Psalm 16:4-6. Oor die onmiskenbaar magiese element van die Roomse sakramentsopvatting en die heidense oorsprong daarvan (kyk bv Hislop, 1959:129-144, 156-164) kan hier nie uitgewei word nie. Dit is egter noodsaaklik om duidelik te onderskei tussen heidense beelde en begrippe wat deur die Christene oorgeneem en met 'n nuwe. Bybelse inhoud gevul is (Schulze, 1996:141-154) en, aan die ander kant, heidense opvattings en rites wat "ongekersten" die Christendom binnegesluip het. 
Reformasie as herstel van die ware diens van Gad: enkele aanwysers by Camyn en Zwingli

uit twee verskillende gesigshoeke gesien, naamlik in die letterlike en figuurlike (metaforiese) betekenis daarvan.

Calvyn onderstreep die letterlike betekenis van die liggaam in die diens van God. Dit hou in dat die uitwendige, sigbare seremonies (die gedraginge van die mens) nie irrelevant is nie. In die preek is daar meer as een aanwysing daartoe. In die eerste geval erken Calvyn dat God inderdaad in opregtheid van hart (in gees en waarheid) gedien wil word. Maar, so werp hy tee, dit beteken nie dat die uitwendige gedrag sonder betekenis is nie. Hiervoor beroep Calvyn hom op die Skrif, wat spreek van die buig van die knieë en die ophef van die hande, en van Daniel en sy vriende wat geweier het om Nebukadnesar se beeld te aanbid. Teenoor 'n tweede groep ("verloopte" Protestante) erken Calvyn dat God ons hart vra. Dit beteken egter nie dat ons dubbelhartig kan wees nie. Ware integriteit in die diens van God hou immers in, sê Calvyn, dat die liggaam nie anders as die hart sal handel nie, want die liggaam behoort ook aan Christus.

Hierdie aksent op die liggaam hou in dat daar nie aan die afgodiese Roomse seremonies van die Mis deelgeneem sal word nie - 'n gedagte wat Calvyn reeds in sy vroeë traktate uitspreek (kyk voetnoot 3 ) en wat hy ook in duidelike taal in 'n brief van Oktober 1541 aan die Hertogin van Ferrara oordra:

Should someone object that externals of religion are quite indifferent, that what is required is only that the heart should be upright, to that our Lord answers, that He will be glorified in our body, which He has purchased with His blood, that he requires the confession of the mouth, that all our prayers should be consecrated to his honour without being in any way contaminated or defiled by anything despleasing (sic) Him (aangehaal deur Wallace, 1988: 134).

Vanuit die tweede gesigshoek kom Calvyn se gebruik van die menslike bestaan (liggaam en siel) as metafoor na vore. Ons kan dit tipeer as die flguurlike betekenis van die liggaam in onderskeiding van, en in samehang met die siel. Hy gebruik die beeld van liggaam en siel om die twee nature van Christus in die eenheid van sy Persoon toe te lig, én om die communicatio idiomatum te verduidelik (Inst. 2.14.1; Kayayan, 1997b:130). In sy voorlegging aan Karel V gebruik hy dit om die bestaan van die kerk te illustreer: die leer en die rus van die gewete in die barmhartigheid van God is die siel van die kerk, terwyl die kerkorde, pastoraat en "all other matters of order" die liggaam, wat deur die siel geaktiveer word, afbeeld (C. Tr. 1:126-127; vgl. Calvyn, 1958).

In die lig van bostaande twee gesigspunte moet die volgende gekonkludeer word:

- Calvyn het die liggaam ernstig opgeneem en daarmee allerlei opvattings oor Platoniese invloede, dualisme, en spiritualiserende tendense, waaraan hy sou ly, die nek ingeslaan (Davis, 1994) 
- Calvyn het, anders as die meeste van sy tydgenote, gesoek na 'n gepaste uitwendige vorm van die kerk wat die waarheid van die evangelie kan uitdruk (Wallace, 1988:134).

\section{Die brug van liturgie na lewe: die gebed}

Die brandpunt van die herstel van die ware diens van God lê in die kerk. Die kerk, wat volk van God is, moet kennis hê van God soos Hy waarlik is, naamlik die bron van waarheid, geregtigheid, wysheid en verlossing. Sonder hierdie kennis kan Hy nie reg en opreg gedien word nie. In die reformasie van die kerk word die lewewekkende openbaringswoord weer op die voorgrond gestel. Die transformerende krag van die Woord word werksaam; die genadige en soewereine beloftes word deur die sakramente beseël en gelowig omhels. Só kry God sy eer en word sy barmhartigheid geroem. Hier, in die reformasie van die kerk, begin die ware diens van God, en die preek oor Psalm 16:4-6 toon hoe hartstogtelik daarvoor gestry is.

Die kerk is egter geen eiland nie. Dit bestaan uit mense - mense wat elke dag in die volle lewe staan. Daarom loop reformasie van die kerk uit op reformasie van die lewe. Die oorgang van liturgie na lewe, of, van die kerk met sy ampte, orde en liturgie na die "wêreld" word soms treffend in die gebede van Calvyn geillustreer.

Die kommentaar op Maleagi is eintlik voorlesings van opeenvolgende perikope wat telkens met 'n gebed afgesluit word. Hier word twee voorbeelde (in die Engelse vertaling van Beveridge) aangehaal.

Die eerste volg op die behandeling van Maleagi 2:13-16. Die hele gebed staan (soos die perikoop) in die kader van die verbond. Elemente van die preek oor Psalm 16 val op: volharding in die waarheid (van die Woord), vashou aan die plegtige belofte (pledge) van ons geloofsbelydenis. Dan verskuif die aandag na die verhouding met mekaar, in besonder die verhouding van huweliksmaats (kyk Mal. 2:14).

Grant, Almighty God, that though we daily in various ways violate the covenant which thou hast been pleased to make with us in thine only-begotten Son, we may not yet be dealt with according to what our defection, yes, the many defections by which we daily provoke thy wrath against us, do fully deserve; but suffer and bear with us kindly, and at the same time strengthen us that we may persevere in the truth and perform to the end the pledge we have given to thee, and which thou didst require from us in our baptism, and that we each of us may so conduct ourselves towards our brethern, and husbands towards their wives, that we may cherish that unity of spirit which thou hast consecrated between us by the blood of thine own Son - Amen (Calvyn, 1979:562). 
Die tweede gebed sluit die uiteensetting van Maleagi 3:4-8 af. Hierin word die etiese aspek nog sterker as in die vorige gebed beklemtoon. Dis interessant om daarop te let dat die geheel in die teken van die "amp van die gelowige" staan 'n onderwerp wat in teenswoordige toerustingsprogramme (bv. "Ken jou gawes") en kleingroepe hoog aangeskrewe staan. Anders as in die moderne tendense is die priesterskap van die gelowiges in die gebed nie indiwidualisties na binne gerig nie (eie opbou, geloofservaring, ens.) maar na buite, met die volle lewe in die visier. Ook anders as in moderne kursusse en metodes van "kerkbou", word die ampte nie gedegradeer tot randverskynsels nie. ${ }^{9}$ Hier volg die gebed.

Grant, Almighty God, that since thou hast been pleased to choose us as priests to thyself, not that we may offer beasts to thee, but consecrate to thee ourselves, and all that we have, $-O$ grant, that we may with all readiness strive to depart from every kind of uncleanness, and to purify ourselves from all defilements, so that we may duly perform the sacred office of priesthood, and thus conduct ourselves towards thee with chasteness and purity; may we also abstain from every evil work, from all fraud and all cruelty towards our brethem, and so to deal with one another as to prove through our whole life that thou art really our Father, ruling us by thy Spirit, and that true and holy brotherhood exists between us; and may we live justly towards one another, so as to render to each his own right, ${ }^{10}$ and thus show that we are members of thy only-begotten Son, so as to be owned by him when he shall appear for the redemption of his people, and shall gather us into his celestial kingdom - Amen (Calvyn, 1979:586).

\section{Toespitsing: evangelie, rente en besit}

Oor die Reformasie en die ekonomie is daar nie net artikels nie maar selfs boeke geskryf. Wat hier volg, is 'n bloot sketsmatige aanduiding van Calvyn se belangrike bydrae in hierdie verband as besondere voorbeeld van wat die

9 In sy fyn analise van Calvyn se kommentaar op Maleagi (en veral van die gebede) toon T.F Torrance aan dat Calvyn die priesterskap van die gelowiges handhaaf, maar daamaas ook die leraar as priester in besondere sin sien (kyk T.F. Torrance, 1997:63-74, veral p. 70-74). Wat die degradering van die amptelike erediens deur voorstanders van kleingroepe betref, kyk Aucamp (1997:35) se brief, wat sê: " ... die hele trant van die artikel (oor kleingroepe - L.F.S.) is negatief teenoor die erediens as samekoms van die hele gemeente"

10 In hierdie woorde kom due probleem van "menseregte" in die gesigsveld - óók in Inst. 2.845 , waar die agste gebod verklaar word as: "Die doel van die gebod is dat ons aan elkeen moet gee wat hom toekom, want ongeregtigheid is vir God 'n gruwel"; en later, nadat verskillende vorme van diefstal aangedui is: "Hierdie onreg vind nie net in die geval van geld, handel of landbou plaas nie maar in alles waarop iemand geregtig is" (my kursivering) Tog soek ons tevergeefs na 'n demonstratiewe afdwing van "my regte". My naaste kry dit wat hom regtens toekom wanneer ek, kragtens die gebod van liefde, my plig nakom: "Ten slotte moet elkeen daarop let in hoverte hy volgens sy amp teenoor andere verplig is, en wat hy aan hulle verskuldig is, moet hy te goeder trou vereffen" (Inst. 2.846 ) 
Reformasie as herstel van die ware diens van God vir die (ekonomiese) lewe ingehou het.

Die tradisionele kerklike opvatting was dat die neem van rente niks anders as woeker en selfverryking is nie, en die Konsilie van Elvira (306) het hierdie praktyk verbied en die ban uitgespreek oor persone wat hulle aan hierdie misdryf vergryp. Hierdie opvatting oor die boosheid om rente te neem, was deels gegrond op die renteverbod van sekere Ou-Testamentiese tekste (bv. Eks. 22:25; Lev. 25:33-38; Deut. 23:19-20; Ps. 15:5). Dit was egter veral gegrond op Aristoteles se opvatting van die onvrugbaarheid van geld. Aristoteles het hierdie waarheid as 'n aksioma van die natuurwet beskou. In Latyn is dit later presies geformuleer: nummus nummum non parit - geld kan nie kleintjies kry nie.

Calvyn het hierdie Aristoteliaanse wysheid verwerp en 'n onderskeid gemaak tussen konsumptiewe rente (waar armes leen om te kan oorleef) en produktiewe rente (waar geleen word vir 'n onderneming waar deur arbeid self geld gegenereer word). In die eerste geval verbied die Skrif rente; in die tweede geval is die neem van 'n billike rente op grond van die goue reel (Matt. 7:12) gewettig anders het die lener alleen die voordeel.

Ook privaatbesit was 'n problematiese saak vir die Christene vanweë Griekse invloed. Die Grieke het immers gedroom van 'n goue verlede toe almal alles gemeenskaplik besit het. Hierdie opvatting is deur die kerkvaders van die vierde eeu net so oorgeneem, met die gevolg dat party van hulle die sondeval in terme van die verkryging van privaatbesit gesien het. Ambrosius, die beroemde biskop van Milaan, het dit pittig geformuleer: "nature, therefore, has produced a common right for all, but greed has made it a right for a few" (aangehaal deur Schulze, 1985:19-20).

Vir Calvyn was privaatbesit egter geen probleem nie omdat hy dit sien as veronderstelling van die agste gebod. Hy hamer daarop dat God in sy vrymag sy gawes (geestelik en stoflik) in ongelyke mate uitdeel - nie om dié wat baie ontvang in gierigheid te stimuleer nie, maar om as rentmeesters mededeelsaam te wees en die algemene welvaart te bevorder.

Op grond van bogenoemde ingrypend nuwe beskouings van Calvyn oor rente en besit het sommige sosioloë die Calvinisme as bakermat van die kapitalisme gesien. Dit is egter 'n siening ten onregte. Calvyn het immers ook radikaal ander geluide laat hoor. As die Raad van Geneve sy advies vra oor die sosioekonomiese probleme wat die duisende vlugtelinge in die stad geskep het, beveel hy aan die Raad as "vader van die volk" onder meer die volgende aan: prysbeheer op die basiese lewensmiddele, indiensopleiding van werkloses, skepping van werksgeleenthede, gratis mediese versorging vir die armes. In die lig van 
Reformasie as herstel van die ware diens van God: enkele aanwysers by Cahyn en Zwingli

bogenoemde aanbevelings sou 'n mens Calvyn ook as vader van die sosialisme kan sien. Dit sou ook 'n verkeerde beskouing wees.

Ons sal duidelik moet insien dat die populêre keuse tussen kapitalisme en sosialisme, wat voortdurend aan ons opgedring word, 'n vals dilemma is. Calvyn se Bybelse beskouing transendeer die dilemma: God is die eienaar van alles en deel sy gawes verskillend uit sodat die mens as rentmeester in verantwoordelikheid aan sy naaste en aan die samelewing diensbaar kan wees (vir 'n algemene oorsig oor Calvyn en die ekonomie kyk Esser, 1997; Schulze, 1985).

\section{Ware diens van God omvat die lewe}

The Gospel and the Word of God directly characterise the Reformation which sprang from them. These terms denote so much more than part of an order of service - they burst through all the structures and they themselves create the divine service which they seek (Locher, 1981:11).

Hierdie treffende tipering van die Reformasie maak Locher na aanleiding van Zwingli se werk en opvattings. Maar as tipering van die Reformasie geld dit net so goed van Calvyn (Schummer, 1997; Esser, 1997). Trouens, al die Hervormers was diep onder die indruk van die transformerende krag van die verkondigde Woord. Luister ten slotte na die verwondering en jubeltone hieroor in Zwingli se verklaring van sy Vyfde Artikel (1523):

Where the Spirit of God is, there one knows well ... that the highest service of God in the faith is to do good to one's neighbour. Wherever one trusts in God, there is God. Where God is, there is also careful diligence in all that is good ... Here I could, indeed, speak of men, whose names I prefer not to mention, who are progressing excellently - eternal praise and thanks to God! - in love to God, in peace with their neighbour, in the knowledge of the Gospel, in simplicity of life, in godly wisdom, in giving alms and help to the poor, in humbling their pride, in forgiving their enemies, in concern for the teaching of Christ, in concem for the prisoners of Christ and in concern for the whole of Christ's people ... They reduce the rents of their tenants, they pay the labourer more than he dares to demand, they invite the poor and wretched into their homes ... (Zwingli, Samtliche Werke, II:47 e.v., aangehaal deur Locher, 1981:4-5).

\section{Samevatting}

'n Traktaat oor die reformasie van die kerk, 'n polemiese preek, twee gebede, rente en besit - almal van Calvyn - en Zwingli se lofsang op die krag van die Woord was ter sprake. Elk belig op sy eie manier die implikasies en omvang van die ware diens van God. In hierdie veelkantige beligting word die mankemente van ons tyd duidelik sigbaar: die redusering van godsdiens tot Privalsache, met die gevolglike onmag en onwilligheid om as sout en lig in die samelewing te dien; die visie op die Reformasie as 'n blote "kerklike saak"; die toenemende mens- 
gesentreerdheid in die prediking - 'n tendens wat uitloop op moralisme waar baie van die mens se inspanning, maar weinig van die krag van die Woord verwag word

In die "nuwe Suid-Afrika" moet die volk van God hande vat, nie kop in die sand steek nie maar na bo kyk en die moue oprol - paraat in die ware, lewensomvattende diens van God

\section{Bibliografie}

AUCAMP, C. 1997, 'n Stem van waarskuwing Brief. Die Kerkblad, 100(3021):35, Okt. 8.

C. $\mathrm{Tr}=$ Calvin's tracts and treatises kyk Calvyn, J 1958.

CALVYN, J. 1870. Opera quae supersunt omnia, vol. 8. Ed. Baum, G., Cunitz, E., Reuss, E. Brunsvigae : Schwetschke et filium. (= CO.)

CALVYN, J 1941. Het gepredikte Woord. Preken van Johannes Calvijn. Vert. door J Douma en W.H van der Vegt. Dl. 5. Franeker : Wever

CALVYN, J, 1958. Tracts and treatises on the Reformation of the church. Transl. by H. Beveridge Historical notes and introduction by T.F. Torrance. Grand Rapids : Eerdmans

CALVYN, J. 1979. Commentaries on the Prophet Malachi Transl. by J. Owen. Repr. Grand Rapids Baker. (Calvin's Commentaries, vol. 15.)

CALVYN, J 1986. Institusie van die Christelike godsdiens. Vert. deur HW. Simpson Dl. 2 Potchefstroom : CJBF

$\mathrm{CO}=$ Opera quae supersunt omnia kyk Calvyn, J. 1870

DAVIS, T.J. 1994. Not 'hidden and far off': The bodily aspect of salvation and its implications for understanding the body in Calvin's theology. Calvin Theological Journal, 29(2):406-418

DE JONG, P.Y. 1967. Calvin's contributions to Christian education Calvin Theological Journal, 2(2):162-201.

DE KROON, M. 1997. Freedom and bondage. Martin Bucer on the sanctification of the Sunday. (In Neuser, W.H., Selderhuis, H.J., Van't Spijker, W., eds. Calvin's books. Festschrift for Peter de Klerk Heerenveen : Groen. p 271-282.)

ESSER, H.H 1997. Calvin's concept of property in view of the introduction of a new monetary order (In Neuser, W H., Selderhuis, H.J., Van't Spijker, W., eds. Calvin's books. Festschritt for Peter de Klerk. Hecrenveen : Groen. p. 149-174.)

GANOCZY, A. 1987. The young Calvin. Transl. by D. Foxgrover and W. Provo. Philadelphia Westminster.

HISLOP, A. 1959. The two Babilons. 2nd American ed Neptune, N.J. : Loizeaux.

KAYAYAN, E. 1997a. Vertaling van Excuse de Jehan Calvin a Messieurs les Nocodemites (1544) Calvin Theological Journal, 29(2)346-363.

KAYAYAN, E. 1997b. La portée cognitive du langage figure dans le texte Francais de l'Institution de la religion Chrestienne de Jean Calvin. Potchefstroom : PU vir CHO. (M A-verhandeling.)

KÜNG, H. 1969 The church. Transl. by Ray and Rosaleen Ockenden. 3rd impr. London : Burns \& Oats.

LOCHER, G.W. 1981. Zwingli's thought: New perspectives Leiden : Brill

MANNS, P. 1983 Martin Luther Freiburg : Herder

PARKER, T.H.L. 1992. Calvin's preaching. Louisville, Ky. : Westminster

PETER, R. 1984. Geneve dans la predication de Calvin. (In Neuser, W H., ed. Calvinus ecclesiae genevensis custos. Frankfurt a.M. : Peter Lang p 23-48.)

SCHULZE, L F. 1985. Calvin and 'social ethics'. Pretoria : Kital

SCHULZE, L.F. 1992 Calvyn en die Akademie van Geneve. Koers, 57(3):305-317

SCHULZE, L.F. 1996. Ons belydenis: Grieks of Kosher? In die Skriflig, 30(2):141-154 
Reformasle as herstel van dle ware dlens van God: enkele aanwysers by CaMyn en Zwingll

SCHUMMER, L. 1997. Un aspect méconnu, oubliè, perdu, cache ... de la synthèse de Calvin: la repartition des richesses (In Neuser, W.H., Selderhuis, H.J., Van't Spijker, W., eds. Calvin's books. Festschrift for Peter de Klerk. Heerenveen : Groen. p 133-148.)

SCHüTZEICHEL, H. 1997. Calvins Auslegung der drei Cantica in der Lukanischen Vorgeschichte. (In Neuser, W.H., Selderhuis, H.J., Van't Spijker, W., eds. Calvin's books. Festschrift for Peter de Klerk. Heerenveen : Groen. p. 75-94.)

TORRANCE, T.F. 1997. Legal and evangelical priests: the holy ministry as reflected in Calvin's prayers. (In Neuser, W H., Selderhuis, H.J., Van't Spijker, W., eds. Calvin's books. Festschrift for Peter de Klerk. Heerenveen : Groen. p. 63-74)

VAN DER WAI,T, J.L. 1984. The school that Calvin established in 1559. (In Van der Walt, B.J., ed Our Reformational tradition. Potchefstroom : PU vir CHO. p. 300-338.)

WALLACE, R.S. 1988. Calvin, Geneva, and the Reformation. Grand Rapids : Baker 